\title{
Erratum to: Invasions in Marine Communities: Contrasting Species Richness and Community Composition Across Habitats and Salinity
}

\author{
H. Jimenez ${ }^{1}$ - E. Keppel ${ }^{2,3}$ - A. L. Chang ${ }^{1}$ - G. M. Ruiz ${ }^{2}$
}

Published online: 28 August 2017

(C) Coastal and Estuarine Research Federation 2017

Erratum to: Estuaries and Coasts.

https://doi.org/10.1007/s12237-017-0292-4

The authors inadvertently omitted the following Acknowledgments from the original article:

The authors would like to thank G. Ashton, L. Ceballos, R. DiMaria, S. Havard, C. Kostecki, K. Larson, L. McCann, S. Thibaut, and C. Zabin for assistance in field sampling, data collection, and data management. We thank J. Carlton, J. Cordell, P. Fofonoff, L. Harris, and G. Hendler for generous assistance and advice on taxonomy and biogeography (i.e., non-native status of organisms). This work was funded by the Marine Invasive Species Program at California Department of Fish and Wildlife and also the Smithsonian Institution.

The online version of the original article can be found at https://oi.org/ 10.1007/s12237-017-0292-4

H. Jimenez

jimenezh@si.edu

1 Smithsonian Environmental Research Center, 3150 Paradise Drive, Tiburon, CA 94920, USA

2 Smithsonian Environmental Research Center, 647 Contees Wharf Road, Edgewater, MD 21037, USA

3 Italian National Research Council (CNR), ISMAR Institute of Marine Sciences, Arsenale di Venezia, Tesa 104,

I-30122 Venice, Italy 